\title{
Effect of Non-Esterified Fatty Acids on Fatty Acid Metabolism-Related Genes in Calf Hepatocytes Cultured in Vitro
}

\author{
Peng Liab Yiming Liu ${ }^{c}$ Yi Zhang ${ }^{a}$ Miao Long ${ }^{a}$ YangGuo ${ }^{a}$ Zhe Wang ${ }^{b} \quad$ Xinwei Li ${ }^{b}$ \\ Cai Zhang $^{d}$ Xiaobing Li ${ }^{b}$ Jianbin He ${ }^{a}$ Guowen Liu \\ aCollege of Animal Science and Veterinary Medicine, Shenyang Agricultural University, Shenyang, \\ 'Key Laboratory of Zoonosis, Ministry of Education, College of Veterinary Medicine, Jilin University, \\ Changchun, 'Department of Foreign Language Education, Shenyang Agricultural University, Shenyang, \\ ${ }^{d}$ College of Animal Science and Technology, Henan University of Science and Technology, Luoyang, \\ China
}

\section{Key Words}

Non-esterified fatty acids $\bullet$ Metabolism $\bullet$ Hepatocytes $\bullet$ Dairy cows

\begin{abstract}
Background: NEFA plays numerous roles in the metabolism of glucose, lipids, and proteins. A number of experimental studies have shown that NEFA may have an important role in fatty acid metabolism in the liver, especially in dairy cows that experience negative energy balance (NEB) during early lactation. Methods: In this study, using fluorescent quantitative RT-PCR, ELISA, and primary hepatocytes cultured in vitro, we examined the effect of NEFA $(0,0.2,0.4$, $0.8,1.6$, and $3.2 \mathrm{mmol} / \mathrm{L}$ ) on fatty acid metabolism by monitoring the mRNA and protein expression of the following key enzymes: long chain acyl-CoA synthetase (ACSL), carnitine palmitoyltransferase IA (CPT IA), long chain acyl-CoA dehydrogenase (ACADL), and acetylCoA carboxylase (ACC). Results: The mRNA and protein expression levels of ACSL and ACADL markedly increased as the concentration of NEFA in the media was increased. The mRNA and protein expression levels of CPT IA were enhanced significantly when the NEFA concentrations increased from 0 to $1.6 \mathrm{mmol} / \mathrm{L}$ and decreased significantly when the NEFA concentrations increased from 1.6 to $3.2 \mathrm{mmol} / \mathrm{L}$. The mRNA and protein expression of ACC decreased gradually with increasing concentrations of NEFA. Conclusion: These findings indicate that increased NEFA significantly promote the activation and $\beta$-oxidation of fatty acids, but very high NEFA concentrations may inhibit the translocation of fatty acids into mitochondria of hepatocytes. This may explain the development of ketosis or liver lipidosis in dairy cows. CPT IA might be the key control enzyme of the fatty acid oxidation process in hepatocytes.
\end{abstract}

Copyright (C) 2013 S. Karger AG, Basel 
Li et al.: Effect of NEFA on Fatty Acid Metabolism -Related Genes

\section{Introduction}

Non-esterified fatty acids (NEFA) are one of the most important metabolites in the serum of dairy cows, especially in the transition period (3 weeks before to 3 weeks after parturition). During the transition period, dairy cows experience an increased demand for energy to support milk production, but dry matter intake (DMI) is only insufficient. As a result, a negative energy balance (NEB) occurs. In response to this, lipolysis occurs to provide precursors of molecules used for energy, and it causes an increase in the NEFA serum concentrations [1-3]. NEFA play numerous potential roles in many metabolic disorders and other diseases of periparturient cows $[4,5]$.

For cows, the liver plays an essential role in fatty acid metabolism. Large amounts of NEFA are metabolised in the liver via 3 main pathways: (1) complete oxidation, producing $\mathrm{H}_{2} \mathrm{O}, \mathrm{CO}_{2}$, and ATP; (2) incomplete oxidation, producing ketones; and (3) esterification to triacylglyceride. When the uptake of NEFA exceeds the oxidation ability of the liver, more NEFA will be incompletely oxidised to ketones or esterified to triacylglyceride, leading to ketosis or fatty liver syndrome [6]. Acyl-CoA synthetase long-chain (ACSL), carnitine palmitoyltransferase IA (CPT IA), and acyl-CoA dehydrogenase long chain (ACADL) are important rate-limiting enzymes relevant to fatty acid oxidation that are in responsible for fatty acid activation, translocation, and $\beta$-oxidation in mitochondria. Acetyl-CoA carboxylase (ACC), which converts acetyl-CoA to malonyl-CoA, is an inhibitor of CPT I [7]. While experiencing a NEB, a high blood NEFA concentration may affect the enzymes listed above and alter fatty acid oxidation metabolism. However, the process of fatty acid oxidation under high NEFA concentrations is unclear. Therefore, the objective of this study was to determine the effects of NEFA on the mRNA and protein expression in cultured bovine hepatocytes of the enzymes listed above. This study provides important information for understanding the mechanism of metabolic disorders in dairy cows.

\section{Materials and Methods}

\section{Cell culture}

Hepatocytes were cultured using the collagenase perfusion method described previously [8, 9]. Briefly, the liver (caudate lobe) was obtained under sterile conditions from a Holstein newborn calf anesthetised with thiamylal sodium. Then, the liver was quickly transferred into a superclean bench, washed with perfusion solution, and digested with digestion solution. After digestion, $100 \mathrm{~mL}$ of basic medium was added to the tissue, and the liver capsule, blood vessels, fat, and connective tissue were removed. Any parts of the liver caudate lobe that were incompletely digested were cut away, and the remainder of the liver parenchyma was cut into pieces and filtered sequentially with 100-mesh $(150 \mu \mathrm{m}), 200$-mesh $(75 \mu \mathrm{m})$, and 500 -mesh $(30 \mu \mathrm{m})$ cell sieves. The hepatocyte suspension obtained was washed twice with basic medium $\left(4^{\circ} \mathrm{C}\right)$ and centrifuged for $10 \mathrm{~min}$ at $50 \times \mathrm{g}$ before resuspension in adherent medium. The hepatocyte purity was assessed using flow cytometry, and it was above $95 \%$. The cell density was adjusted to $5 \times 10^{5}$ cells $/ \mathrm{mL}$ with adherent culture medium, and the cells were cultured in six-well plates at a density of $10^{6} \mathrm{cells} / \mathrm{cm}^{2}$ (Costar, New York, USA, Corning Incorporated). After a 4-hr attachment period, the media that contained unattached cells was replaced with RPMI 1640 culture medium containing $10 \%$ fetal bovine serum. The cells were then cultured at $37{ }^{\circ} \mathrm{C}$ and $5 \% \mathrm{CO}_{2}$. Every $24 \mathrm{hr}$, the media of each well was replaced with fresh media.

\section{NEFA treatments}

The preparation of the NEFA solution was performed as described previously by Li et al. [8]. Oleic acid (2.175 mmol), linoleic acid (0.245 mmol), palmitic acid (1.595 mmol), stearic acid (0.72 mmol), and palmitoleic acid $(0.265 \mathrm{mmol})$ were dissolved in $100 \mathrm{~mL}$ of a potassium hydroxide solution (1 mol/L) at $60^{\circ} \mathrm{C}$. Hydrochloric acid ( $\left.1 \mathrm{~mol} / \mathrm{L}\right)$ was used to adjust the $\mathrm{pH}$ of the NEFA solution to 7.2 , and then the solution was diluted to a final volume of $500 \mathrm{~mL}$ with distilled water. Therefore, the concentration of the 
Table 1. Primers used for the analysis of the expression of fatty acid metabolism-related genes

\begin{tabular}{|c|c|c|c|c|}
\hline Gene name & Sequence of primers $\left(5^{\prime}-3^{\prime}\right)$ & $\begin{array}{c}\text { Length of } \\
\text { amplicon (bp) }\end{array}$ & $\begin{array}{c}\text { GenBank } \\
\text { accession no. }\end{array}$ & $\begin{array}{c}\text { Annealing } \\
\text { Temperature }\left({ }^{\circ} \mathrm{C}\right)\end{array}$ \\
\hline ACSL & $\begin{array}{l}\text { Forward: TCGGAACTGAAGCCATCACC } \\
\text { Reverse: GCCTCGTTCCAGCAGATCAC }\end{array}$ & 173 & NM_001076085 & 58 \\
\hline CPT IA & $\begin{array}{l}\text { Forward: CAAAACCATGTTGTACAGCTTCCA } \\
\text { Reverse: GCTTCCTTCATCAGAGGCTTCA }\end{array}$ & 111 & BF039285 & 54 \\
\hline ACADL & $\begin{array}{l}\text { Forward: CCCAGGTTTTGGTCTTCATTCA } \\
\text { Reverse: GGCTCTGTCATTGCTATGGCA }\end{array}$ & 132 & NM_001076936 & 58 \\
\hline ACC & $\begin{array}{l}\text { Forward:TGCTGAATATCCTCACGGAGCT } \\
\text { Reverse:CGACGTTTCGGACAAGATGAGT }\end{array}$ & 212 & NM_174224 & 60 \\
\hline$\beta$-actin & $\begin{array}{l}\text { Forward: GTCATCACCATCGGCAATGAG } \\
\text { Reverse: GCTAACAGTCCGCCTAGAAGCA }\end{array}$ & 403 & NM_173979 & 57 \\
\hline
\end{tabular}

NEFA stock solution was $10 \mathrm{mmol} / \mathrm{L}$, and the solution contained $4.35 \mathrm{mmol} / \mathrm{L}$ oleic acid, $0.49 \mathrm{mmol} / \mathrm{L}$ linoleic acid, $3.19 \mathrm{mmol} / \mathrm{L}$ palmitic acid, $1.44 \mathrm{mmol} / \mathrm{L}$ stearic acid, and $0.53 \mathrm{mmol} / \mathrm{L}$ palmitoleic acid.

At $72 \mathrm{hrs}$, the media was replaced with RPMI 1640 culture medium free of foetal bovine serum with NEFA added. The final concentrations of NEFA in the media were $0,0.2,0.4,0.8,1.6$, and $3.2 \mathrm{mmol} / \mathrm{L}$. As a control experiment, different concentrations of potassium chloride ( $\mathrm{KCl}$ ) was added into the media, and the final concentrations of potassium were $0,2,4,6,8,10 \mathrm{mmol} / \mathrm{L}$. The experiments for each treatment concentration of NEFA and potassium chloride were replicated 3 times.

\section{RNA extraction and real-time RT-PCR}

After $24 \mathrm{hrs}$ of incubation, the total RNA of the hepatocytes was extracted. Total RNA was isolated from hepatocytes using RNAiso ${ }^{\mathrm{TM}}$ Plus (TaKaRa Biotechnology (Dalian) Co., Ltd., Dalian, China) according to the manufacturer's instructions and was quantified by spectrophotometry with a Biophotometer (VaudauxEppendorf, Basel, Switzerland). Only samples with an optical density ratio at 260/280 nm were used in further analyses. Then, $1 \mu \mathrm{g}$ total RNA was reverse transcribed with $200 \mathrm{U}$ Moloney Murine Leukemia Virus Reverse Transcriptase RNase H Minus, Point Mutant (Promega, Madison, WI) using 100 pmol random hexamer primers (Invitrogen, Leek, Netherlands). The cDNA $(25 \mathrm{ng} / \mu \mathrm{L})$ was amplified by fluorescent quantitative RT-PCR using SYBR Premix Ex Taq ${ }^{\mathrm{TM}}$ ॥ (TaKaRa Biotechnology (Dalian) Co., Ltd., Dalian, China), according to the manufacturer's instructions. A master mix of the following reaction components was prepared: $6 \mu \mathrm{L}$ of water, $0.8 \mu \mathrm{L}$ of forward primer $(10 \mu \mathrm{mol} / \mathrm{L}), 0.8 \mu \mathrm{L}$ of reverse primer $(10 \mu \mathrm{mol} / \mathrm{L}), 10 \mu \mathrm{L}$ of SYBR Premix Ex Taq ${ }^{\mathrm{TM}} \|(2 \times)$, and $0.4 \mu \mathrm{L}$ ROX reference dye (50x). Then, $18 \mu \mathrm{L}$ of master mix and $2 \mu \mathrm{L}$ of sample volume (containing 50 ng of cDNA) were used in the following 2-step PCR program: denaturation for $30 \mathrm{~s}$ at $95^{\circ} \mathrm{C}$ and 40 cycles of amplification (each cycle consisting of $5 \mathrm{~s}$ at $95^{\circ} \mathrm{C}$ and $60{ }^{\circ} \mathrm{C}$ for $30 \mathrm{~s}$ ). Then, the PCR products were submitted to a melting curve program $\left(60-95^{\circ} \mathrm{C}\right)$. The expression of the ACSL, CPT IA, ACADL, and $\beta$-actin genes were evaluated on the basis of mRNA copy number per $1 \mu \mathrm{g}$ of total RNA. The $\beta$-actin gene was also analysed (in addition to the target genes of interest) to monitor the efficiency of the RT-PCR and to provide an internal reference. The target gene mRNA abundance was displayed as the target gene mRNA copy number per $1 \mu \mathrm{g}$ of total RNA divided by the $\beta$-actin mRNA copy number. The primers for CPT IA were identical to that of van Dorland et al. [10], and the primers for ACSL, ACADL, ACC, and $\beta$-actin were designed using Primer Express ${ }^{\mathrm{TM}}$ Version 2.0 software (PE Applied Biosystems, Foster, CA, USA) (Table 1). The primers for ACSL and ACADL were designed to detect them in the mitochondria.

\section{Protein extraction and enzyme activity determination}

After a $24 \mathrm{hr}$ incubation, the cells were harvested from the culture dishes by scraping, recovered by sedimentation and stored at $-80{ }^{\circ} \mathrm{C}$ prior to analysis. The frozen cell pellets containing approximately $25 \times 10^{6}$ cells/treatment group ( 3 dishes) were homogenised in $0.1 \mathrm{M}$ of potassium phosphate (pH 7.4), 1 mM EDTA and 20\% glycerol with a Dounce manual homogeniser. The particulate matter was removed by centrifugation for $2 \mathrm{~min}$ at $10,000 \times \mathrm{g}$ and was stored in aliquots at $-80^{\circ} \mathrm{C}$. Total protein was assayed using the Bradford protein assay reagent (Bio-Rad, Hercules, CA) with bovine serum albumin as the standard.

The ACSL protein level was measured using the bovine acyl-CoA synthase enzyme-linked immunosorbent assay (ELISA) kit (cat. no. CSB-E12165B) with a minimum detectable concentration of 
$0.39 \mathrm{ng} / \mathrm{mL}$, and the interassay and intraassay coefficients of variance were $6.1 \%$ and $3.4 \%$, respectively. The CPT IA protein level was measured using the bovine carnitine palmitoyltransferase I ELISA kit (cat. no. CSB-E12136B) with a minimum detectable concentration of $0.31 \mathrm{ng} / \mathrm{mL}$, and the interassay and intraassay coefficients of variance were $7.2 \%$ and $4.7 \%$, respectively. The ACADL protein level was measured using the bovine long chain acyl-coenzyme A dehydrogenase ELISA kit (cat. no. CSB-E12138B) with a minimum detectable concentration of $3.12 \mathrm{ng} / \mathrm{mL}$, and the interassay and intraassay coefficients of variance were $6.3 \%$ and $4.5 \%$, respectively. The ACC protein level was measured by using the bovine acyl-CoA carboxylase

Fig. 1. Agarose gel electrophoresis of hepatocyte total RNA.

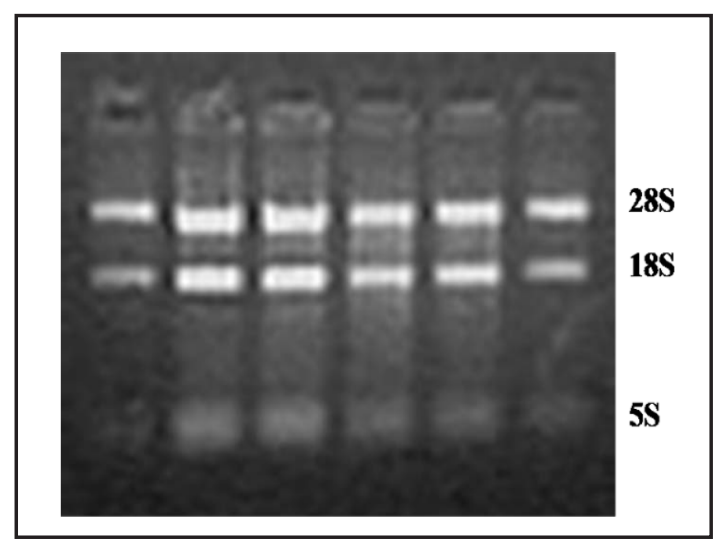
ELISA kit (cat. no. CSB-E12139B) with a minimum detectable concentration of $0.78 \mathrm{ng} / \mathrm{mL}$, and the interassay and intraassay coefficients of variance were $9.4 \%$ and $5.4 \%$, respectively. All kits were obtained from Cusabio Biotech Co. Ltd., Wuhan, China and were used according to the manufacturer's instructions. Each factor was measured in triplicate. The protein expression of ACSL, CPT IA, ACADL, and ACC were displayed as target protein content/total protein content.

Statistical analyses

Statistical analyses of the data were conducted using the SPSS 13.0 software (SPSS Inc., Chicago, IL) with a significance level of $P<0.05$. The values were expressed as the means $\pm \mathrm{SD}$. Parameters were compared by one-way ANOVA using the Duncan's test.

\section{Results}

Agarose gel electrophoresis of hepatocyte total RNA

As shown in Fig. 1, three bands of hepatocyte total RNA, corresponding to $28 \mathrm{~S}, 18 \mathrm{~S}$ and 5S RNA, were found. The $A_{260} / A_{280}$ ratio of total RNA was $>1.9$ and met the specified purity requirements.

The $m R N A$ and protein expression of fatty acid metabolism-rated genes

As shown in Fig. 2, different potassium concentrations did not significantly affect the mRNA expression of ACSL, CPT IA, ACADL, and ACC in hepatocytes $(P>0.05)$.

Low NEFA concentrations $(\leq 0.4 \mathrm{mM})$ did not significantly affect the mRNA and protein expression of ACSL in hepatocytes (Fig. 3). However, the ACSL mRNA and protein expression were markedly increased when the NEFA concentration exceeded $0.8 \mathrm{mM}(P<0.05)$.

As shown in Fig. 4, increasing CPT IA mRNA and protein expression were observed when the NEFA concentration was less than $1.6 \mathrm{mM}(P<0.05)$, and decreasing CPT IA mRNA and protein expression were observed when the NEFA concentration exceeded $1.6 \mathrm{mM}(P<$ 0.05).

As shown in Fig. 5, the mRNA and protein expression of ACADL increased gradually with increasing concentrations of NEFA. The ACADL mRNA and protein expression were markedly increased when the NEFA concentrations exceeded $0.4 \mathrm{mM}(P<0.05 ; \mathrm{mRNA})$ and $0.8 \mathrm{mM}(P<0.05$; protein). Low concentrations of NEFA $(\leq 0.2 \mathrm{mM})$ did not significantly affect the mRNA and protein expression of ACADL in hepatocytes.

As shown in Fig. 6, the mRNA and protein expression of ACC decreased gradually with increasing concentrations of NEFA. The ACC mRNA and protein expression were markedly decreased when the NEFA concentrations exceeded $0.8 \mathrm{mM}(P<0.05 ; \mathrm{mRNA})$ and $1.6 \mathrm{mM}$ $(P<0.05$; protein). Low concentrations of NEFA $(\leq 0.4 \mathrm{mM})$ did not significantly affect the mRNA and protein expression of ACC in hepatocytes. 
Fig. 2. Effects of potassium chloride on the mRNA expression of ACSL, CPT IA, ACADL, and ACC. Means not sharing a common superscript are significantly different from each other $(P<0.05)$.
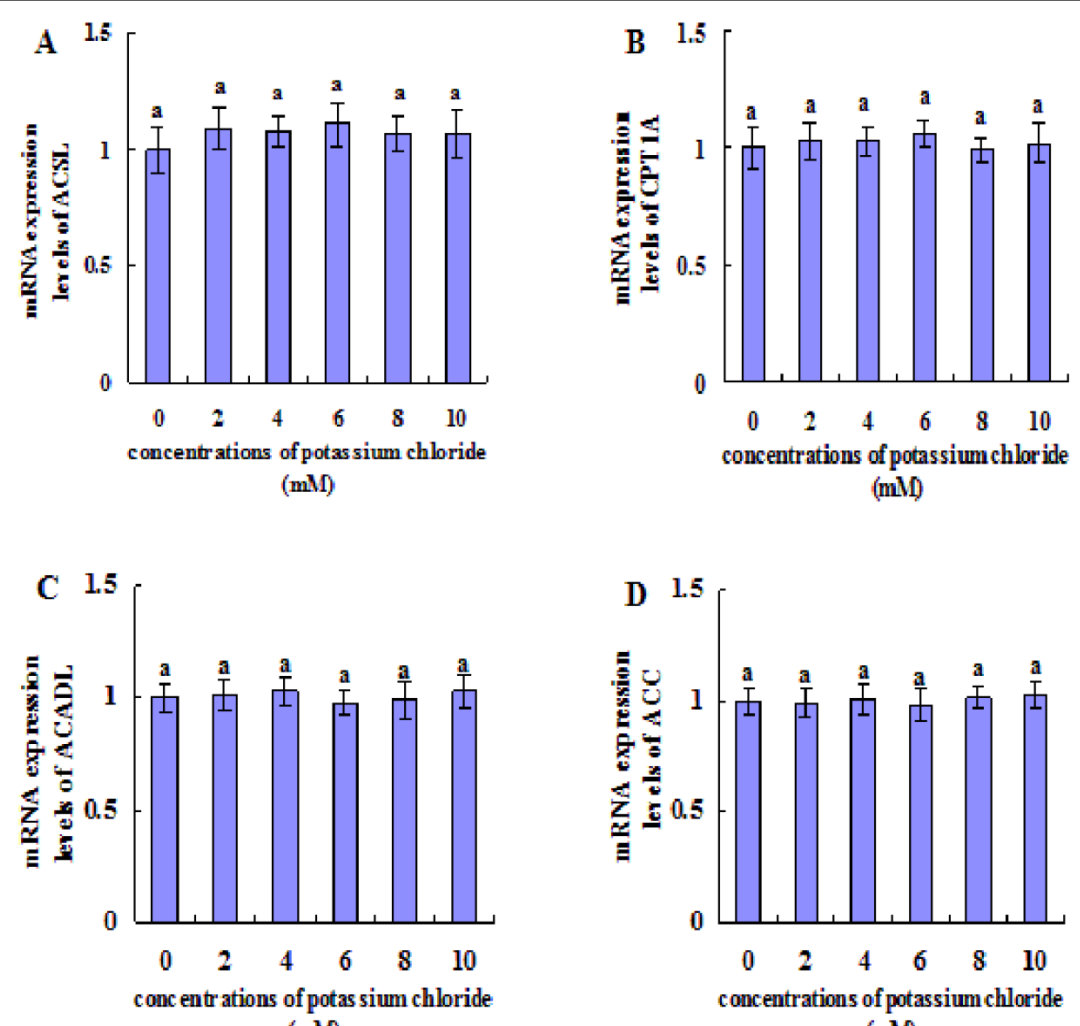

$(\mathrm{mM})$

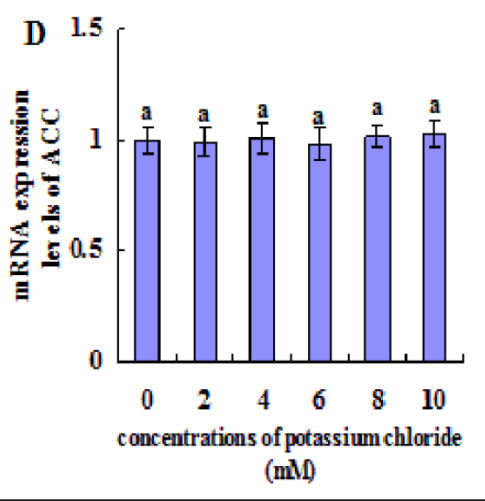

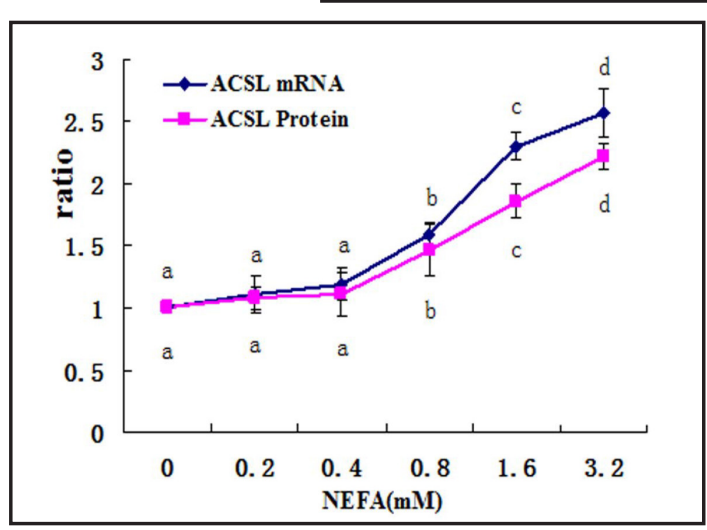

Fig. 3. Effects of NEFA on ACSL mRNA and protein expressions. Note: Values are means \pm SD. Different small letters, a, b, c, and d indicate significant difference between the parameters of ACSL mRNA or ACSL protein $(P<0.05)$, and the same small letters indicate no significant difference between different concentration sets in the same line $(P>0.05)$.

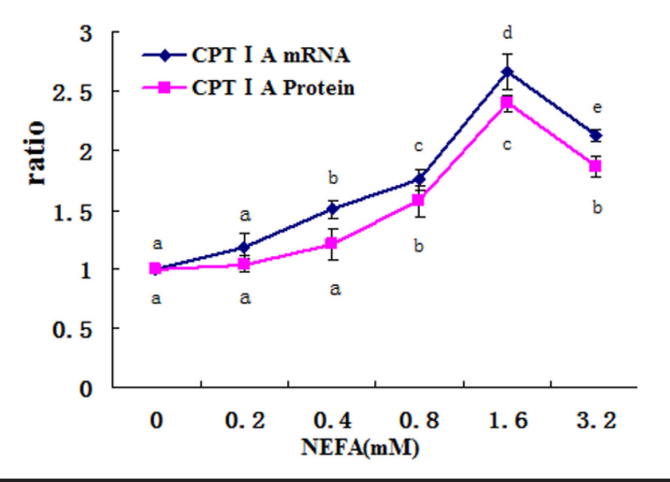

Fig. 4. Effects of NEFA on CPT IA mRNA and protein expressions. Note: Values are means \pm SD. Different small letters, a, b, c, d, and e indicate significant difference between the parameters of CPT IA mRNA or CPT IA protein $(P<0.05)$, and the same small letters indicate no significant difference between different concentration sets in the same line $(P>0.05)$.

\section{Discussion}

Dairy cows usually experience a NEB during the transition period; this is especially seen in high yield cows and is accompanied by decreased energy intake, which leads to fat mobilisation and a significant increase in the blood NEFA concentration. NEFA are mainly oxidised in the liver to generate ATP for cows. In addition to a metabolic substrate, NEFA also act as signalling molecules involved in many metabolic processes, such as glucose 


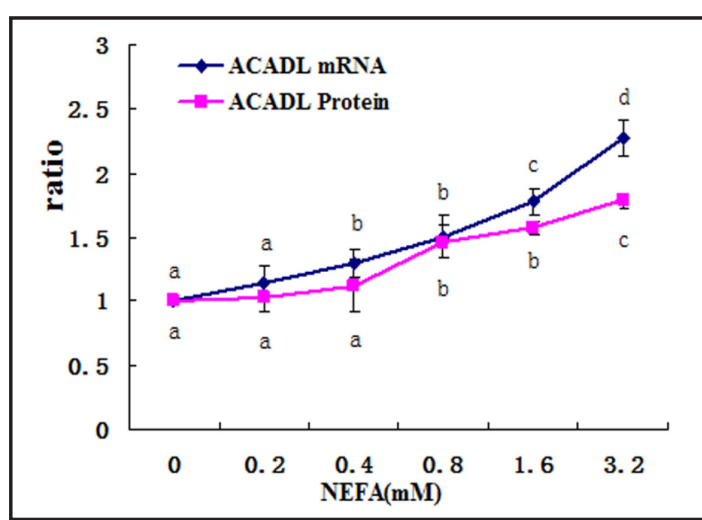

Fig. 5. Effects of NEFA on ACADL mRNA and protein expressions. Note: Values are means \pm SD. Different small letters, a, b, c, and d indicate significant difference between the parameters of ACADL mRNA or ACADL protein $(P<0.05)$, and the same small letters indicate no significant difference between different concentration sets in the same line $(P>0.05)$.

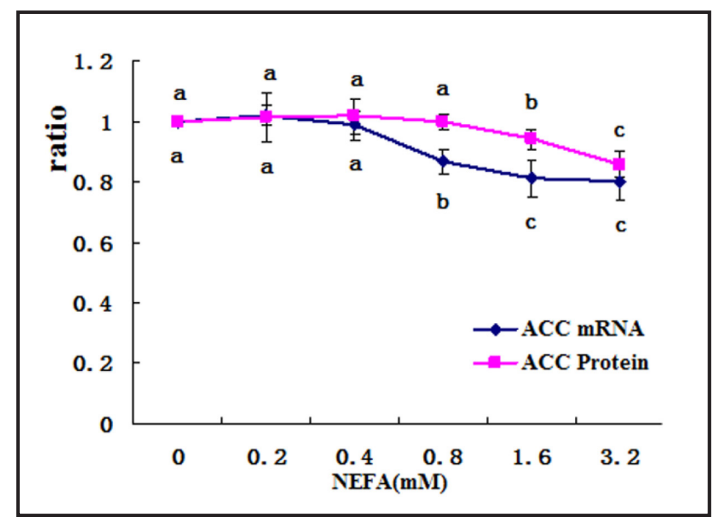

Fig. 6. Effects of NEFA on ACC mRNA and protein expressions. Note: Values are means \pm SD. Different small letters, $a, b$, and c, indicate significant difference between the parameters of ACC mRNA or ACC protein $(P<0.05)$, and the same small letters indicate no significant difference between different concentration sets in the same line $(P>0.05)$.

metabolism and insulin resistance $[8,11,12]$. However, the effect of NEFA on fatty acid metabolism in dairy cows was unclear, especially at high NEFA concentrations. In previous studies, at normal conditions, the serum NEFA was lower than $0.4 \mathrm{mmol} / \mathrm{L}$ in dairy cows, but this was always greater than $0.5 \mathrm{mmol} / \mathrm{L}$ in cows in the transition period [13]. Furthermore, the serum NEFA concentrations in dairy cows with severe NEB have always been found to be above $1.5 \mathrm{mmol} / \mathrm{L}$ [14]. Therefore, we treated the hepatocytes with $0,0.2,0.4,0.8,1.6$, and 3.2 $\mathrm{mmol} / \mathrm{L}$ NEFA to observe the effects of high concentrations of NEFA on fatty acid metabolism in bovine hepatocytes. The hepatocytes were treated with different concentrations of NEFA, and also treated with different concentrations of potassium. But our results demonstrated that the solvent of NEFA did not markedly affect the expression of ACSL, CPT IA, ACADL, and ACC in bovine hepatocytes.

In liver cells, fatty acid oxidation mainly occurs in mitochondria [15]. The 4 steps of mitochondrial fatty acid oxidation are activation, translocation, $\beta$-oxidation, and ketogenesis [16]. ACSL, CPT IA, and ACADL are key enzymes that control the activation, translocation, and $\beta$-oxidation of fatty acids in the mitochondria. In the present study, the mRNA and protein expression of ACSL and ACADL increased gradually with increasing concentrations of NEFA. These results indicate that a high NEFA level may increase fatty acid oxidation in mitochondria. For CPT IA, increasing mRNA and protein expression were observed when the concentration of NEFA was less than $1.6 \mathrm{mmol} / \mathrm{L}$, and decreasing mRNA and protein expression were observed when the concentration was more than $1.6 \mathrm{mmol} / \mathrm{L}$. These results were similar to those found by $\mathrm{Xu}$ et al. [17]. ACSL activates fatty acid metabolism to fatty acyl-CoA leading to either fatty acid oxidation or triacylglyceride synthesis in the liver [7]. ACADL is an enzyme that catalyses the first step of the $\beta$-oxidation of long chain FA in the mitochondria. Our results indicate that although increasing NEFA led to increased ACSL and ACADL expression in hepatocytes, high concentrations of NEFA (more than $1.6 \mathrm{mmol} / \mathrm{L}$ ) also inhibited the expression of CPT IA, a membrane transporter that transfers fatty acids (acyl$\mathrm{CoA}$ ) from the cytoplasm into the mitochondrial matrix and is a primary regulatory enzyme involved in mitochondrial $\beta$-oxidation [16]. In spite of the increase in fatty acid metabolism to fatty acyl-CoA, fatty acyl-CoA transport into the mitochondrial matrix was limited; thus, the oxidation of fatty acids in the mitochondria is bounded. The fatty acyl-CoA level is increased due to the increased expression of ACSL; this fatty acyl-CoA may be esterified to triacylglyceride, which may result in liver lipidosis. Therefore, CPT IA might be the key control enzyme of the fatty acid oxidation process in the mitochondria. Louet reported that 
long-chain FA oxidation is primarily controlled by changes in CPT I activity, malonyl-CoA concentration, and the sensitivity of CPT I to inhibition by malonyl-CoA [16]. In this study, the expression of ACC, which converts acetyl-CoA to malonyl-CoA, was inhibited when the concentration of NEFA in the media increased; this resulted in a decrease in the production of malonyl-CoA. This result may explain why the mRNA and protein expression of CPT-IA were enhanced significantly when the NEFA concentrations increased from 0 to $1.6 \mathrm{mmol} / \mathrm{L}$. However, the effects of NEFA on the activity and sensitivity of CPT IA were not evaluated in the present study, and additional research is needed to confirm our findings.

Our in vivo results indicated that significant changes in fatty acid oxidation genes occurred in ketotic cows that experience a NEB and that increased serum NEFA concentrations were positively correlated with ACSL expression and negatively correlated with ACADL and ACC expression [7]; the mechanism underlying these results was unclear. Recently, studies have indicated that the AMP-activated protein kinase (AMPK) signalling pathway plays a key role in the regulation of hepatic lipid metabolism [18]. Increased plasma TG content and hepatic lipogenesis were observed when AMPK $\alpha$ was deleted in mice, but plasma TG content was decreased when AMPK $\alpha$ was overexpressed in the liver [19, 20]. Li's results showed that NEFA can activate the AMPK signalling pathway to regulate the expression of lipid metabolism-related enzymes in bovine hepatocytes, including ACC, ACSL, and CPT IA; this then affects fatty acid oxidation in these cells [21]. Our results indicate that, as signalling molecules, NEFA also affect fatty acid oxidation through the activation of the AMPK pathway, which may explain the changes in the expression of fatty acid oxidation-related genes in our study. Our findings may aid to the understanding of the concentration-dependent effect of NEFA on hepatic fatty acid oxidation.

\section{Conclusions}

In summary, the results of this study indicate that high concentrations of NEFA significantly promote hepatocyte fatty acid oxidation by increasing the activation and $\beta$-oxidation of fatty acids. However, high NEFA concentrations (more than $1.6 \mathrm{mmol} / \mathrm{L}$ ) significant inhibited CPT IA, reducing fatty acid transport into the mitochondria, decreasing fatty acid oxidation, and potentially leading to ketosis and liver lipidosis. CPT IA may play a key role in fatty acid oxidation in bovine hepatocytes.

\section{Acknowledgements}

This work was supported by the Program for New Century Excellent Talents in University (NCET-11-0199), the National Key Technology R\&D Program (grant no. 2012BAD12B03), the National Natural Science Foundation of China (Beijing, China; grant no. 30871897, 30972224, 31072178, 31172372, 31172172, 31201961, 31272621 and 31361233), the Program Funded by Liaoning Province Education Administration (grant no. L2013264), the Dr. Startup Fund of Liaoning Province (grant no. 20131103), and the National Spark Plan Project of China (grant no. 2011GA650001).

\section{References}

1 Wathes DC, Cheng Z, Fenwick MA, Fitzpatrick R, Patton J: Influence of energy balance on the somatotrophic axis and matrix metalloproteinase expression in the endometrium of the postpartum dairy cow. Reproduction 2011;141:269-281.

2 Xu C, Wang Z, Liu GW, Li XB, Xie GH, Xia C: Metabolic characteristic of the liver of dairy cows during ketosis based on comparative proteomics. J Anim Sci 2008;21:1003-1010. 
3 Wathes DC, Clempson AM, Pollott GE: Associations between lipid metabolism and fertility in the dairy cow. Reprod Fertil Dev 2013;25:48-61.

4 Duplus E, Glorian M, Forest C: Fatty acid regulation of gene transcription. J Biol Chem 2000;275:3074930752.

-5 Jump DB, Botolin D, Wang Y, Xu J, Christian B, Demeure O: Fatty acid regulation of hepatic gene transcription. J Nutr 2005;135:2503-2506.

6 Adewuyil AA, Gruysi E, van Eerdenburg FJCM: Non esterified fatty acids (NEFA) in dairy cattle. A review. Vet Q 2005;27:117-126.

7 Li P, Li XB, Fu SX, Wu CC, Wang XX, Yu GJ, Long M, Wang Z, Liu GW: Alterations of fatty acid $\beta$-oxidation capability in the liver of ketotic cows. J Dairy Sci 2012;95:1759-1766.

8 Li XW, Li XB, Bai G, Chen H, Deng QH, Liu ZX, Zhang L, Liu GW, Wang Z: Effects of non-esterified fatty acids on the gluconeogenesis in bovine hepatocytes. Mol Cell Biochem 2012;359:385-388.

-9 Zhang ZG, Li XB, Gao L, Liu GW, Kong T, Li YF, Wang HB, Zhang C, Wang Z, Zhang RH: An updated method for the isolation and culture of primary calf hepatocytes. Vet J 2012;191:323-326.

10 van Dorland HA, Richter S, Morel I, Doherr MG, Castro N: Variation in hepatic regulation of metabolism during the dry period and in early lactation in dairy cows. J Dairy Sci 2009;92:1924-1940.

11 Mashek DG, Grummer RR: Effects of long chain fatty acids on lipid and glucose metabolism in monolayer cultures of bovine hepatocytes. J Dairy Sci 2003;86:2390-2396.

12 Michael R, Thomas BP, Gianluca P, Kitt FP, Douglas LR, Gary WC, Gerald IS: Mechanism of free fatty acidinduced insulin resistance in humans. J Clin Invest 1996;97:2859-2865.

13 Samiei A, Liang JB, Ghorbani GR, Hirooka H, Yaakub H, Tabatabaei M: Anevaluation of beta-hydroxybuty rate in milk and blood for prediction of subclinical ketosis in dairy cows. Pol J Vet Sci 2010;13:349-356.

14 Yang Z, Huang KH, Hou JF, Mao XZ, Yu ZH: Study on Lipid mobilization in dairy cows with ketosis and after parturition. J Nanjing Agric Univ 1993;16:134-138.

15 Drackley JK, Overton TR, Douglas GN: Adaptations of glucose and long-chain fatty acid metabolism in liver of dairy cows during the periparturient period. J Dairy Sci 2001;84:E100-E112.

16 Louet JF, Le May C, Pegorier JP, Decaux JF, Girard J: Regulation of liver carnitine palmitoyltransferase I gene expression by hormones and fatty acids. Biochem Soc Trans 2001;29:310-316.

17 Xu C, Wang Z, Zhang RH, Zhang HY, Fu SX, Xia C: Effect of NEFA and glucose levels on CPT-I mRNA expression and translation in cultured bovine hepatocytes. J Vet Med Sci 2011;73:97-101.

18 Christine S, Sabina B, Sandra H, Ulrike K, Dirk A, Harald MH, Monika R, Bjorn K: Increased Anaplerosis, TCA cycling, and oxidative phosphorylation in the liver of dairy cows with intensive body fat mobilization during early lactation. J Proteome Res 2012;11:5503-5514.

19 Andreelli F, Foretz M, Knauf C, Cani PD, Perrin C, Iglesias MA: Liver adenosine monophosphateactivated kinase-alpha 2 catalytic subunit is a key target for the control of hepatic glucose production by adiponectin and leptin but not insulin. Endocrinology 2006;147:2432-2441.

-20 Foretz M, Ancellin N, Andreelli F, Saintillan Y, Grondin P, Kahn A: Short-term overexpression of aconstitutively active form of AMP-activated protein kinase in the liver leads to mild hypoglycemia and fatty liver. Diabetes 2005;54:1331-1339.

21 Li XW, Li XB, Chen H, Lei LC, Liu JX, Guan Y, Liu ZX, Zhang L, Yang WT, Zhao CX: Non-esterified fatty acids activate the AMP-activated protein kinase signaling pathway to regulate lipid metabolism in bovine hepatocytes. Cell Biochem Biophys DOI: 10.1007/s12013-013-9629-1. 